\title{
"Our Generation..." Aspiration, Desire, and Generation as Discourse Among Highly Educated, Portuguese, Post-austerity Migrants in London
}

\author{
Lisa Rodan ${ }^{1}$ D $\cdot$ Roy Huijsmans ${ }^{2}$ \\ Accepted: 17 September 2020 / Published online: 29 September 2020 \\ (c) European Association of Development Research and Training Institutes (EADI) 2020
}

\begin{abstract}
Drawing on 18 months of multi-sited ethnographic fieldwork, this paper brings into dialogue empirical material from young, highly educated Portuguese migrants in London, theoretical work on desire in migration studies and sociological approaches to theorising aspirations. The paper argues that young migrants' narratives of migration shed important light on the working of aspirations in the processes of becoming through migration. Such orientations towards the future are shaped by young migrants' engagements with doxic and habituated logics producing aspirations. The analytical lens of desire illuminates the role of discursive self-positioning, emotions, and the embodiment of lived experiences of migration in the enacting of particular migrant subjectivities and associated aspirations. In a context in which competing discourses of generation constitute important registers of meaning about migration and aspirations, mobilising generation discourses is a key temporal practice in young migrants' constructions of narratives of migration.
\end{abstract}

Keywords Generation · Migration · Aspiration · Desire · Youth · Crisis

\section{Résumé}

Cet article s'appuie sur 18 mois de travail ethnographique de terrain sur plusieurs sites et met en relation des données empiriques issues de jeunes migrant.e.s portugais.es hautement qualifié.e.s à Londres, avec des travaux théoriques sur le désir dans les études sur les migrations et avec des approches sociologiques pour théoriser les aspirations. L'article soutient que les récits de migration des jeunes migrant.e.s of-

Lisa Rodan

lvr2@kent.ac.uk

Roy Huijsmans

huijsmans@iss.nl

1 School of Anthropology and Conservation, Marlowe Building, University of Kent, Canterbury, Kent CT2 7NR, UK

2 International Institute of Social Studies of Erasmus University, Kortenaerkade 12, 2518 AX The Hague, The Netherlands 
frent un éclairage important sur le fonctionnement des aspirations dans le processus de devenir qui en en jeu lors de la migration. Ces orientations vers l'avenir sont façonnées par les logiques doxiques et habituelles auxquelles les jeunes migrant.e.s font appel, et qui produisent des aspirations. Le prisme analytique du désir éclaire le rôle du positionnement discursif, des émotions et de l'incarnation des expériences vécues de la migration dans la mise en œuvre des subjectivités particulières des migrant.e.s et des aspirations associées. Dans un contexte où les discours simultanés de différentes générations constituent des registres importants du sens de la migration et des aspirations, une pratique dans l'air du temps pour les jeunes migrant.e.s repose sur la construction de leurs récits de migration en mobilisant les discours de différentes générations.

Them [her parents], they never worked outside of Portugal, they left university and both got jobs, that's what people did then...My generation, we are more curious, we want to see the world, but also it has more opportunities than in Portugal. We were the generation of Erasmus that inspired a lot of people to travel. (Cecilia, 23 years, in London since 2017 working as a babysitter and for catering companies).

...our generation, we were told a lie. In the past people always migrated because they didn't have many studies and couldn't find a job back home. So my parents always said, get a degree so you can get a good job and you won't have to migrate. Why did they tell me that, if in the end, I had to migrate anyway and life here is so hard? (Joana, 25 years, in London since 2015 working as a nurse).

\section{Researching Migration, Generation, and Aspiration}

In migration studies, the concept of aspiration has long been used for understanding why people move (e.g. Carling 2002). Yet, if we appreciate migration as a social process that continues to unfold throughout migrating (Collins 2018, p. 966; De Haan and Rogaly 2002, pp. 6-7), we need to expand the analytical scope of aspiration to include processes of becoming through migration. We would suggest that this is especially important in relation to young migrants whose becoming through migration intersects with becoming from a life course perspective (see Huijsmans et al., this volume). The central aim of the article is to tease apart this becoming dimension of migration to understand how it is both driven by and generative of aspirations. Empirically we do so on the basis of ethnographic material about the construction of migration narratives by young, highly educated, Portuguese migrants in London. Our contribution to theorising aspirations is that we bring this empirical material into dialogue with sociological approaches to the formation of aspiration (e.g. Zipin et al. 2015) and Collins' work (2018) on 'desire' through migration. Thereby, the article gets deeper into the embodied, enacted, and emotional work of aspiration, 
which in the processes of becoming of the young Portuguese migrants is deeply intertwined with the temporal logic provided by specific discourses of generation.

The process of becoming through migration is a temporal one. In relation to the young Portuguese migrants featured in this study, temporality not only matters theoretically and conceptually (as we elaborate below), it also matters empirically. The research participants on whom this article is based had all moved to London some years after the global financial crisis at a time when the immediate and harshest impact of the austerity measures that were rolled out in Portugal in response to the crisis had already passed. Therefore, our study population is different from those in studies conducted at the height of the crisis. Yet, as we demonstrate, the discursive legacy of crisis still featured prominently in some young migrants' narratives of migration.

The analysis presented in this article is based on the empirical material produced through numerous interactions of Lisa, the first author, with two young Londonbased Portuguese migrants, Cecilia and Joana (names have been changed to ensure anonymity). Cecilia and Joana were among the ten young migrants with whom Lisa developed an in-depth research relationship over the period 2015-2018. ${ }^{1}$ The stories of Cecilia and Joana represent two common, yet different ways in which the young, highly educated, post-austerity Portuguese migrants narrated their becoming through migration, producing very different orientations towards the future. ${ }^{2}$ Discourses of generation were central in these narratives as the two excerpts at the start of this article emphasise. In addition to this temporal dimension, we also tease apart how the multiple relations, places, and objects young migrants pull together in constructing their narratives of migration produce particular affects that perhaps do not translate into neatly and coherently articulated sets of aspirations, but nonetheless shed light on how young migrants position themselves in relation to desired futures.

As a relatively young, London-based woman with a migrant background (BritishMexican) and with Portuguese as a third language, the research relationship Lisa developed with the participants became part of their migration assemblages. That is, it became embedded in the collection of places, actors, practices, and other relations and elements through which migration unfolds (Collins 2018). Since Lisa had worked as an English language teacher previously and many of her participants lacked confidence in the English language, especially at the outset of the research, the meetings were conducted in a mix of Portuguese and English interspersed with bits of language teaching. Given the relational context through which the research interactions unfolded, discussions about aspirations and the realities of their lives in London came forth almost naturally. These encounters would often 'reveal the empirical disjuncture between expectations of migration [...] and the actual experiences of migrants' (Lawson 2000, p. 174, in: Collins 2018, p. 969). Following

\footnotetext{
1 These ten were drawn from a larger pool of nearly 40 Portuguese migrants (aged 20-40) with whom Lisa started the research.

${ }^{2}$ Cecilia and Joana did not know each other. As the ethnographic material suggests, they were indeed part of very different social circles and were leading very different lives despite the many characteristics they shared.
} 
Collins, these disjunctures draw 'attention to forms of agentive will, expressions of desire, as well as the social structures that these emerge within and exceed' and illuminate how narratives of migration are constructed in relation to "pasts that constitute migrant becoming and future possibilities that are desired but not yet accounted for' (Collins 2018, p. 969). The research participants' migration assemblages were further researched through meeting up with their social networks, including visiting their families back home in Portugal. This allowed the triangulation of the narratives the young migrants constructed themselves with insights from relevant others. The point of such triangulation was not to arrive at a greater level of truth, but rather to think more with elements and dimensions that were left unsaid or appeared contradictory in young migrants' own narratives.

We have organised the article as follows. In the next section, we situate the production of aspiration and the role of generation discourse therein in relation to the broader historical and politico-economic context of Portuguese youth migration. Thereafter we present ethnographic descriptions of the migration narratives constructed and enacted by Cecilia and Joana, two young, highly educated, Londonbound, Portuguese post-austerity migrants. In the sections that follow we theorise these narratives in relation to sociological work on the social production of aspirations and work on desire as a social force operating through migration. We conclude by arguing that the conceptual lens of desire is helpful for illuminating how aspirations are articulated in an embodied and emotional manner as young migrants seek to become 'more than just a migrant' through the process of migration (Collins 2018, p. 978), but also acknowledge that a focus on discursive (self)representation and performativity may obscure important sets of social relations shaping this very process of being and becoming in and through migration.

\section{Situating Aspirations and Generation in Narratives of Contemporary Portuguese London-Bound Youth Migration}

Throughout the interviews and other research interactions, the young Portuguese migrants we worked with frequently referred to the phrase 'our generation' in their narratives of migration and aspiration (as well as 'their generation' to refer to earlier generations, such as their parents' and their aspirations). By narrating their migrations in relation to discourses of generation, these young migrants 'position themselves in face of the narratives that have become dominant to describe that generation location' (Aboim and Vasconcelos 2014, p. 176).

In childhood and youth studies, the concept of generation has largely been used to analytically account for youth in relation to other age-based groupings as well as in relation to larger processes of continuity and change (e.g. Cole 2004; Edmunds and Turner 2005; Huijsmans 2016; Punch 2020). However, much less attention has been paid to how the idea of generation is understood and mobilised by young people themselves in their subjective self-positioning vis-à-vis their own and other age-based groupings and how through these dynamics certain sets of aspirations are produced, maintained, or reworked. Understanding this more fully requires situating 
our research participants' migrations in relation to Portugal's recent socio-economic history and the role of migration therein.

Portugal joined the European Union (EU) in 1986 after a turbulent decade following the fall of a 50-year fascist dictatorship in 1974. The newly allocated EU funds facilitated an extensive modernisation project, fuelling nation-wide aspirations of transforming from a semi-peripheral country into a fully 'European', 'modern', and 'developed' country (Mapril and Blanes 2018).

Portuguese out-migration rates declined in the year following EU accession. This was a significant development because out-migration had been a structural feature of Portuguese working-class life for a long time (Nóvoa 2014, p. 2839). In addition, it was also seen by the Portuguese urbanised, intermediate strata and bourgeoisie as symbolic of the country's chronic underdevelopment (Mapril and Blanes 2018; Pina-Cabral 2018).

Since the collapse of the Salazar dictatorship, and with further additional spurs after joining the EU, Portuguese educational policy focused on expanding masseducation. This included a rapid increase in tertiary education enrolment rates. EU membership also further diversified the landscape of Portuguese out-migration. EU mobility schemes enabled students from middle-class backgrounds to study in fellow EU member-states (Sin, Tavares, and Neave 2017), whilst the EU's free movement of labour principle enabled Portuguese graduates to seek employment in mostly northern European countries.

In his seminal work Eurostars and Eurocities: Free movement and mobility in an integrating Europe, Adrian Favell (2008) introduces the term 'Eurostars' to refer to highly educated young intra-EU migrants from middle-class backgrounds. They are the 'free movers', who have escaped the confinement of the nation-state, the local community, and family and who are living the EU's post-nation, post-class, panEuropean ideal in so-called 'Eurocities' such as Amsterdam, Brussels, or London.

The aspirations expressed by Cecilia in the opening paragraph and throughout this paper, such as freedom, adventure, and self-development through migration within the EU, can be linked to efforts of the EU to promote intra-EU mobility in the form of campaigns and mobility schemes targeting youth (e.g. Huijsmans 2011). Hence, when Cecilia emphasises that her migration is driven by a sense of curiosity which she sees as characteristic of her 'Erasmus generation', she is articulating aspirations rooted in a doxic logic, grounded in the EUs 'populist-ideological mediations' (Zipin et al. 2015, p. 231).

Despite the various characteristics Cecilia and Joana share, Joana's quote at the top of the paper reflects a very different process of becoming through migration and associated aspirations. Nonetheless, here a discourse of generation is also prominently present in her narrative of migration. The common, yet differentiated references to generation discourse among the highly educated Portuguese migrants underscore that 'migration...is never singular in its temporality, but rather is an ongoing process where past, present and future are folded together in the emergence of migrant lives' (Collins 2018, p. 967). The identity construct of the cosmopolitan, aspirational migrant that Cecilia enacted is fuelled by the affects and desires of the post-nation, post-class, and adventurous Eurostar generation discourse that she mobilised through her migration narrative. In contrast, Joana emphasised very 
different temporalities in her narrative of migration, by relating it to the sentiments of the Portuguese geração a rasca movement (the desperate generation) which emerged at the height of the crisis some years earlier.

When the global financial crisis of 2008 hit Portugal, this was responded to with a series of austerity measures including cuts in government spending in return for IMF bailouts (Cairns, Growiec, and de Almeida Alves 2014; Gray 2016). During the years that followed, youth unemployment doubled to $42 \%$ for the 15-24 age group and $45 \%$ for those with tertiary qualifications (Cairns et al. 2014). Migration figures jumped too, with up to 120,000 Portuguese migrating in 2013 and, for the first time, many of them with some form of tertiary education because of "the dimming of imagined futures' within Portugal (Cairns et al. 2014, p. 1058). The anger about lost future perspectives gave rise to massive youth protests at a scale not witnessed since the revolutionary period (1974-1975), which developed into the so-called geração a rasca movement (Baumgarten 2013; Gray 2016).

Without exception, all the research participants had a story about how their contemporaries were either working in the tourist industry back home, which was typically unrelated to what they had studied, or had migrated to London and other northern European cities in an attempt to pursue the career path they had chosen before austerity measures were put in place and the labour market imploded. The fact that this now also included highly educated youth is what Joana emphasised when she insisted that her generation had 'been lied to'. Through this phrase, Joana put in question the doxic logic of educational qualifications leading to meaningful employment without having to migrate that was largely unquestioned in Portugal's social landscape prior to the financial crisis although far from a reality for all youth (Goulart and Bedi 2017). As will become clear through the ethnographic material presented below, frustration stemming from the realisation of 'being lied to', however, was also generative of more pragmatic and life phase specific sets of aspirations.

\section{Constructing Migration Narratives}

\section{Cecilia: Our Generation as Adventurous}

It was a blustery February evening and Cecilia was about to arrive in one of a handful of new drinking establishments that had recently opened in Deptford, South East London. Cecilia, a 23-year-old aspiring actress from Porto, Portugal's second-largest city, shared a rented house in nearby North Greenwich with several other southern Europeans in their 20s and 30s. This was one of the cheaper parts of the capital to rent a room, although new luxury flats, bars, and restaurants were opening every few months as the area was gentrified. It was one of the most diverse areas of London and walking down its high street at any time of day, conversations in Portuguese, Spanish, and Italian intermingled with African and Middle Eastern tongues.

Cecilia arrived, looking windswept and gazed around the industrial chic décor with a smile. "Nice!" she said, sitting down and removing several layers. Cecilia had arrived in London about six months earlier from Portugal. Her father, Jorge, a psychiatrist and her mother, Fatima, an occupational therapist, both worked at the local 
hospital in Porto. Her two brothers were also abroad, her twin brother completing his undergraduate degree in Graphic Design in Barcelona and her older brother studying for a Master's Degree in Food Technology in Brussels. Cecilia had graduated in Theatre Studies a year earlier and had been working as a waitress in Lisbon whilst applying for acting jobs. Then her landlord had decided not to renew the rental contract on her shared flat.

He said he wanted us out...so his mother could move in apparently. Ha! He wanted it for Airbnb. He knew he could get much more for it than through us. That's what everyone is doing in Lisbon now. So it just seemed like time to go. I had nowhere to live, I was sleeping on a friend's sofa so I thought I'd come to London.

Despite working long hours as a babysitter for a Portuguese family she knew through her mother's network and for several catering companies on the side, Cecilia was always overflowing with enthusiasm about the possibilities London offered for her self-development, from the theatre trips she was taking to the opportunities to learn English and possibly soon enrolling at RADA. ${ }^{3}$

I can do it, I know I'm here for a reason and I think I have the ability to get where I want, I just need to improve my English and then all sorts of things will be available! There are so many opportunities in the career I want. In the future, well I will stand out in Portugal if I go back, having a UK qualification or experience. I mean, everyone in Portugal is emigrating at the moment, here I am one of many, I know that, but back home I think I could stand out, whether it is teaching in a university or doing my own thing, I would still be different. $^{4}$

Cecilia's speech, body language, and reactions to the world around her always conveyed confidence and aspirations for the future. Specifically, aspirations to one day embody the symbolic capital required to be distinct and 'different' from those around her (Bourdieu 1984; Prazeres 2019). Such narratives were very much in the singular and focused on herself as an individual. Cecilia's migration may have been crisis-induced but her reflections lacked the sense of collective anger, betrayal, and hopelessness of the geração a rasca (Gray 2016), the self-identified 'desperate generation' that has featured so prominently in Portuguese youth studies (Cairns et al. 2014; Gray 2016; Knight and Stewart 2016) as well as in the media and popular discourse in the years immediately following austerity, a pattern that soon after could also be observed in Spain (the indignados movement) and Greece (indignant citizens' movement) (Baumgarten 2013). In contrast, Cecilia emphasised her migration as aspirational and 'an adventure'.

\footnotetext{
3 One of London's most prestigious drama schools.

4 When finalising the manuscript in May 2020, Lisa learnt that Cecilia and her siblings had all returned to Portugal and were now all staying in their childhood home. They planned to remain there until the various COVID-19 related partial lockdowns were lifted.
} 
That night in the bar the conversation drifted towards recent political developments in Portugal. Cecilia laughed when asked what she thought of the new Portuguese prime minister.

You have to meet my dad! He is obsessed with politics, the crisis! He talks on and on. Sometimes we just tell him to shut up.

She smiled fondly and her face took on a comic guilty look.

People my age, we don't know or care about politics in Portugal. We grew up knowing we'd probably have to migrate if we wanted to practice a specific career. We have gotten used to it in a way, we don't remember anything different whereas the older ones remember what it was like before, different expectations. My father's generation, he was 18 at the time of the Carnation Revolution $^{5}$ and it marked his life and his way of being, he is very politically active. Even though my family, well we're not rich but we're far from not having a lot of money. But he's always stayed fixed on community.

She paused, and the contrast between what she'd just said about her father's collective generational identity being fixed on 'community' and her own shift to 'we' as focused on individual self-development hung in the air. She continued thoughtfully.

My parent's generation, they worked to support their children in university thinking they [their children] would get a job and so things would be different for them... But people my age... we were prepared for a different future. I know I am lucky, and not everyone is as lucky as me to be able to count on support from their family to emigrate. Many end up working in a café or a shop.

She laughed, suddenly self-conscious.

Yes, I know that's what I'm doing here too! But I'd rather work in a café in London than in Lisbon. With tips here, it's a much better financial situation.

To a question about what her parents thought about her dream of becoming an actress in London she responded with a smile and a shrug, before saying-

Them, they never worked outside of Portugal, they left university and both got jobs, that's what people did then. They know things are different from their generation. People don't get a job when they are 22 any more and work in it for ever. My generation, we are more curious, we want to see the world, and there are more opportunities outside of Portugal. We were the generation of Erasmus that inspired a lot of people to travel.

And all the Portuguese who had gone to France in the 1960s and 1970s? She laughed and shook her head.

5 The overthrowing of the Salazar dictatorship in 1974.

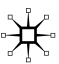


Oh, but that is completely different! It wasn't like today, those people they had less education, they migrated as they had no opportunity to work. It wasn't about personal development.

At this point, Lisa wondered whether to point out that Cecilia had just told her that she had no opportunities to work in Portugal either but Cecilia was on a roll and pointed to herself-

Sometimes I walk to work along the river, passing the beautiful buildings [Old Naval College, Greenwich] and I think about being here and what it means and who I am. I think it's better I came here alone, I have no distractions, I can concentrate on myself and making myself better.

\section{Joana: Our Generation is Being Lied To}

Lisa met Joana through friends of friends. Joana was about the same age as Cecilia and had also recently moved to London to work as a nurse after being enlisted in her final year of her degree by NHS recruiters (the United Kingdom's National Health Service) who visited her university in Portugal. She lived with her boyfriend Marco and his parents and younger brother. Marco worked as a teaching assistant at a secondary school in South London and they both came from a small city called Vila Real in the north of Portugal which Joana described as:

Empty in the winter and full in the summer, when all the migrants come back.

Marco's family had migrated to London in 2003 when he was 11 . He and Joana had met on one of Marco's annual trips home and the two maintained a long-distance relationship for five years before Joana moved to London. Joana was an only child whose parents had both worked in a local factory until her father was signed off sick. Marco's mother had worked in the same factory prior to migration, whilst his father had been the town undertaker. According to Marco, it was a bad debt that his father had taken out that led to their decision to migrate to London, although he later revealed that both of his parents already had siblings there. At the time of research, Marco's dad worked as a delivery driver, whilst his mum worked as a part time cleaner.

Joana often mentioned how 'everyone' in her hometown had migrated at some point, including her own parents and their siblings. She often referred to the fact she hadn't met her father until she was 10 months old because he was away working in a chicken processing factory in Switzerland. Joana's emphasis on generational continuity in narrating her migration was fascinating because it contrasted so starkly with Cecilia's emphasis on generational breaks. These two young women from northern Portugal were virtually the same age, had similar educational backgrounds, had both been exposed to the geração a rasca movement during their formative years, and had migrated to London in Portuguese post-austerity years. Yet, despite these similarities, these two women mobilised the discourse of 'our generation' very differently in their narratives of migration and related aspirations. 
One evening Lisa met Joana in a Portuguese café in the London borough of Lambeth, the heart of South London's Portuguese community, where she lived. ${ }^{6}$ Joana was waiting for Marco, who was teaching an aerobics class of middle-aged Madeiran women in a community centre across the road. Chatting about life in London, Joana explained:

All Marco's family live here, he has so many cousins and their families! Which is good but it means I don't have any British friends. None of us do. Marco's sister, she has her life here, she has lived here since she was 15 and doesn't have any British friends either, not that I know of. She only ever talks about her Portuguese friends. Her husband is Portuguese and she only stays with Portuguese. I think the people here are like that, they stick together. So many people from the same city live here anyway, it's like being in the same place!

This description of her life in London was very different from Cecilia's, who insisted that she had come to London 'alone' and emphasised how she lived, socialised, and worked with other Europeans as well as British. Furthermore, Cecilia also stressed how her new friends were connected not by nationality but by a shared generational identity and educational backgrounds as well as by the aspirational idea of self-development. Whilst Cecilia's narrative echoed that of Favell's (2008) 'Eurostars', the young educated, multi-lingual, and multi-skilled Europeans flocking to 'Eurocities' like London, Brussels, and Amsterdam where they create unique fields of pan-European practices, Joana's account resonated with the Portuguese lorry drivers studied by Nóvoa (2014, p. 2835) whose work makes real the ideal of an integrated European market community, whilst they 'live their professional lives in a kind of nationalised nutshell on wheels'.

Joana's demeanour was generally unenthusiastic and occasionally came out as bitter, especially when she talked about her life in London. Talking about work, she always emphasised how stressful it was. How much harder life in general was than back home. According to her boyfriend Marco, this was because she didn't feel very confident with her English, which affected her performance at work. Yet whenever asked whether she was tempted to go back to Portugal and look for work there, she always shook her head fervently:

Never. You know how much a nurse gets on a bank shift there? Three euros an hour. Even cleaners get five euros. After all that study.

Her eyes had filled with tears at this point and her voice rose.

[In Portugal] It's not just the pay, the patients don't respect you, the work is insecure and there isn't opportunity to learn and get better. And that's the lucky ones! Most nurses have to work two or three jobs. If you have a partner or family to help you out it's better. But without that, you have to work really hard just to pay for everything. Here it is bad to live but I can practice the profession I studied for and I feel valued.

\footnotetext{
${ }^{6}$ About 20,000 Portuguese live in Lambeth.
} 
The importance Joana expressed to feeling valued as a professional in the field she had studied was similar to what Cecilia aspired to. In fact, on first appearances Joana's professional aspiration was central to her decision to migrate. After all, she had moved to London through an NHS recruitment drive. It was only after the research relationship developed that other aspirations emerged which played a much more prominent role in Joana's narrative of migration.

In contrast to Cecilia, Joana channelled her enthusiasm not just into work and an open-ended hope for the future to be realised through the idea of self-development, but more so into relational experiences at a much more localised level and the ongoing potentialities for specific common aspirational goals with Marco, such as buying a house. It was when Joana talked about Marco and their future plans that she brightened up most, enthusiasm shining through her face and radiating through her body language. Yet, she could easily go from giggling about surprise birthday parties for Marco and holidays they were dreaming of, to again remarking about the past and how she had been 'lied to'. In one such moment, she recalled being lectured by her mother about going to university.

Go [study], so you don't end up in factory with no opportunities like me. That's what she said. But our generation, we were told a lie. In the past people always migrated because they didn't have many studies and couldn't find a job back home. So my parents always said, get a degree so you can get a good job and you won't have to migrate. Why did they tell me that, if in the end, I had to migrate anyway and life here is so hard? It makes me angry as I don't want to be here.

Joana's mobilisation of the idea of 'our generation' is very similar to sentiments of the geração a rasca movement of the crisis years (Gray 2016; Cairns et al. 2014). Yet, by mobilising this generation discourse Joana contradicts the narrative of generational continuity regarding migration that she emphasised so strongly at other moments. What's more, Joana simultaneously maintained a pragmatic narrative where she echoed Cecilia almost exactly when recalling what her parents had told her when choosing a degree,

make sure it's something you can do outside, there are not many jobs in Portugal otherwise. I think all Portuguese parents do that, anyone who goes to uni[versity] more or less knows they are going to migrate afterwards, there just aren't enough jobs for all of the people with degrees now, since the [19]80 s when there weren't enough professionals and now there are too many. We've just accepted it.

\section{Desire and Assemblage}

In migration studies, the concept of aspiration is mostly used to refer to the wish to migrate (Carling and Collins 2018, p. 917). Yet, if we appreciate that migration is in most cases not an end in itself but rather a route towards achieving broader life aspirations, then the focus must shift from studying aspirations in 
relation to possibilities for migration (e.g. Carling 2002) towards the transformative potential migrants seek to realise through migration (Carling and Collins 2018). To make this analytical distinction, Collins (2018) proposes the concept of desire, which, in the spirit of Deleuze and Guattari, he describes as 'the energies that draw entities...into relation with each other and in the process generates forms and affects' (Collins 2018, pp. 965-966). In these analytics, discourse matters because 'desire, then, is shaped by discourses that prescribe certain actions and proscribe others, or that code, overcode and decode objects, behaviours and opportunities as more or less desirable' (ibid 2018, p. 968). When Cecilia was reminded that Portuguese had long been involved in migration, she drew on discourses about generation to code her migration as distinct from those Portuguese who migrated to France in the 1960s and 1970s by insisting "they migrated as they had no opportunity to work, it wasn't about personal development".

The strong presence of discourses of generation in young migrants' narratives of migration underscores how through migration multiple temporalities intersect in shaping 'the emergence of migrant lives' (Collins 2018, p. 967). Collins (2018, p. 967) further explains that such 'multiple temporalities of mobility' are articulated 'across migrant bodies and social relations, through places of work and study, to urban, national, regional and global spaces'. These 'arrangements of bodies, things and ideas', which he refers to as 'assemblages', and the concept of desire seek to capture the 'conditions for particular actualisations' this generates (ibid).

These conceptual ideas are reflected in the ethnographic material of how Cecilia and Joana talked about their everyday experience of being in London. It is evident that there is a broader historical and politico-economic context to these young women's migrations, their migrations are also embedded in family biographies, and shaped by various other sets of social relations. Yet, these structuring relations do not determine how these young migrants construct their migrant subjectivities. They exercise agency by articulating the assemblages constituting their migration experience in a particular way. This is not just a discursive practice, the ethnographic material shows that it is performative too and thus embodied and felt. As we will see below, these assemblages might not be fully consistent and coherent but the embodied, affective, and material components that are woven together in these narratives of migration nonetheless produce particular orientations towards the future. As such, desire can be understood as a 'social force' (Carling and Collins 2018, p. 915) generative of certain sets of aspirations.

The agentive dimension in constructing certain migration narratives, for example, is evident when Cecilia did not emphasise the details of her work conditions, and rather stressed the cosmopolitan affect and the idea of self-development through migration. Her narrative further illuminated the importance of enacting her migrant subjectivity, which is an embodied and emplaced experience of being in London. This was most evident when she talked about walking along the river and admiring the beautiful buildings of the Old Naval College in Greenwich. These moments were generative of certain potentialities as they made her "think about being here and what it means and who I am" and how London was "better" for her because she could "concentrate on myself and making myself better". 
In contrast, the assemblage Joana constructed through her migration narrative, including the temporal marker of her use of generation discourse, produced very different affects. Despite the bitterness about having had to leave Portugal in order to realise her professional ambitions, she was positive about her current life and future because working in London allowed her to be with her boyfriend. It was especially in moments when she talked about the future plans the two were making together that she brightened up entirely and showed full enthusiasm for the life ahead of her.

\section{Discontinuities and Contradictions in Migration Narratives}

Over the course of Lisa's research, she heard variations on Cecilia's references to 'adventure' and 'personal-development' as motivational factors for coming to the UK echoed in dozens of conversations with different respondents. These variations were perfectly summarised by a 30 year old from Coimbra who had 'made it' in London, successfully transforming her Portuguese teaching degree into a well-paid position as a brand consultant. Recounting how her parents found her 'alien' for her working practices and ability to change jobs easily, she said

Their generation is afraid to rock the boat, they know if they complain they might not be able to get another job so they just accept things and do nothing!

They don't understand how we can be so adventurous and daring.

Many of these self-identified 'new generation' of migrants, who entered the labour market in the years following Portugal's austerity measures in 2011, were very specific about using their educational attainments and pan-European outlooks as generational markers which distinguished themselves as a generation from previous generations of migrants. This was most significant among those from relatively privileged, mid-status backgrounds who were the first in their families to migrate.

Cecilia was one such individual, neither parents nor grandparents ever having 'needed' to migrate, having enough skills and status to get by in Portugal's dictatorship-era urban environment. She often referred to her childhood travelling around Europe as a 'tourist', a form of mobility which she contrasted firmly with the mobilities of those she described as 'migrants' whom, she stressed, 'had' to migrate. Similarly, she contrasted the desire for adventure she attributed to 'her generation' to the apparent unadventurous previous generation, be it her urban, middle-class parents whom she claimed were satisfied with 'just' getting 'a job', or the 'uneducated' rural migrants of that generation whom according to Cecilia had left Portugal but 'just' wanted to 'work'.

By drawing out such 'generational differences', young migrants like Cecilia emphasised discontinuity and change between generations. This leaves out of sight important relations of continuity that underpinned their migration projects. Indeed, there was a contradiction between young migrants' self-representation as a generation distinct from their parents' generation and their silencing of the material basis that allowed them to enact such subjectivities. After all, the individually constructed notions of aspiration and personhood as a member of a more adventurous generation than their parents were dependent on an intergenerational 
flow of various forms of support from the parental generation to these young migrants. For example, despite Cecilia's frequent claims of 'having arrived on her own', she had been dependent on her employer/family friend from back home for virtually everything, ranging from setting up a bank account, to getting a smartphone to having somewhere to stay and help her find a house-share. When her agreement with her employer ended, Cecilia had been looking forward to 'moving on', yet because nothing substantial was forthcoming she continued to babysit for her and her friends whilst she applied for drama schools and worked for a variety of catering companies. The support of this extended network whose origins were linked to her parents enabled her to engage in the narrative of adventure and self-development which she posited as so different from the forms of migration of 'uneducated people' as well as of her parents' generation.

For young migrants like Cecilia, downplaying the material and relational realities that kept their migrant projects afloat was essential for activating their capacity to aspire. This became even more apparent as offers for auditions started to arrive. When asked if she was eligible for a loan to pay the $£ 12,000$ tuition fees for her Masters, Cecilia smiled broadly and replied:

My parents do lots of overtime to pay for the things that my brothers and I need. They really want us to have as many opportunities as they can give us. I know I am really lucky,"

Her eyes suddenly bright, she hurriedly added:

I mean, I don't depend on them, it's important for me to pay my own way. But I know that if I need something 'big' like a Masters for example they would be happy to help me.

This contradiction with the more immediate discursive formation of 'their unadventurous generation' which was so often presented by Cecilia and other mid-status informants when referring to their parents occurred on a regular basis. In the initial encounters, these university-educated professionals presented themselves as part of an 'adventurous generation', insisting on their autonomy in their decision about having come to London. As the researcher-participant relationship developed and was complemented with research with the participants' relatives in Portugal, these claims did not fade, but were increasingly challenged by the various details they shared about how their migration projects were intricately woven into sets of social relations best characterised as generational continuity rather than the generational break young migrants themselves chose to foreground.

There are discontinuities too in the assemblages constituting the migration narratives of young migrants like Joana who drew on the generation discourse of geração a rasca. The geração a rasca movement conveys a narrative in which the global financial crisis and the way it has affected Portugal destroyed the opportunities for an educated generation coming of age during the crisis, a narrative that is amplified through various popular media (Baumgarten 2013, p. 466). This representation has been critiqued by authors such as Mapril and Blanes (2018) who have typified the geração a rasca movement as a 'middle classification' of 
austerity, which overwrites the longer history of top-down imposed austerity in Portugal. They are referring to the deindustrialisation and subsequent 'desertification' of cities such as Vila Real in northern Portugal starting in the 1980s and 1990s, the period when Marco's family left for London, which was subsequently described by those who benefitted from it not as 'crisis' but the inevitable consequences of modernisation and progress (Mapril and Blanes 2018). This is the same period that was usually referred to as 'the golden years' by those research participants from the major urban centres of Lisbon and Porto such as Cecilia, who were the first in their families to migrate.

Joana came from a working-class background, and she demonstrated a migration habitus through her frequent remarks of how 'everyone' from Vila Real had migrated at some point. This included her own father and most of her boyfriend's family. At the same time, in her migration narrative this migratory habitus was overwritten when she mobilised the generation discourse of the geração a rasca. This enabled her to relate across time, space, and class divides to the narrative of the geração a rasca, for whom migration was seen as a generational break and the only, yet unfair, solution to the realities of Portugal's labour market. By drawing on the geração a rasca narrative as a discursive formation, Joana was able to make sense of her negative feelings around being in London. This counters ethnographies such as those that appeared from Greece, suggesting those who were younger at the onset of austerity were better prepared and less bitter about its effects (Theodossopoulos 2018). This contradiction can be explained by the power of doxic logics. The refrain that if you work hard at school you won't have to migrate that people like Joana constantly heard during her teenage years (and she later reflected on as 'being lied to') were the 'doxic straws of hope to emulate the aspirations of 'the haves"' (Zipin et al. 2015 , p. 235). The frustration over this doxic aspiration was given a place by relating her migration narrative to the geração a rasca discourse. This helped accommodate the negative feelings Joana experienced such as homesickness, exhaustion from long hours, and lack of confidence. Whilst this did not make these negative feelings go away, by literally having linked her fate of migration to that of her boyfriend's her migration nonetheless became transformative as she oriented herself towards more pragmatic and life phase specific aspirations about a future life together with Marco.

\section{Conclusion}

The stories of Cecilia and Joana represent two common, yet different ways in which young, highly educated, post-austerity Portuguese migrants constructed their becoming through migration, producing very different orientations towards the future. We have demonstrated that discourses of generation are a central element in their making sense of their migrations and are constitutive of particular migrant subjectivities and associated aspirations. Our ethnographic material has further illustrated that such narratives are not mere discursive acts; they are enacted, embodied, and felt in a deeply emotional way. In this way, the perpetual process of becoming through migration is both fuelled by and generative of particular sets of aspirations. 
Social science approaches to the theorisation of aspiration draw heavily on Bourdieusian social theory (Appadurai 2004; Stahl et al. 2019; Zipin et al. 2015). As other articles in this Special Issue have demonstrated, such work is extremely helpful in explaining the symbolic violence of aspirations produced through doxic logics or how young people, over the life course, come to adjust their orientations towards the future in, for example, classed and gendered ways (e.g. Huijsmans et al., this issue). However, Bourdieusian approaches are less suitable for analysing aspirations that are in the process of being formed and which cannot be reduced to the workings of doxic or habituated logics. This shortcoming is especially acute when it comes to teasing apart the role of aspirations in processes of becoming through migration in relation to young people.

Cross-border migration, among other things, enables young people to break away from the confines of the home, the family, the local community, and the nation-state, at least at the level of performance and discursive self-positioning (Favell 2008). This is particularly true for the highly educated intra-EU migrants that were the focus of this article. Moreover, for the young migrants featured in this study migration also constituted a process of becoming from a life course perspective, something that was particularly evident from Joana's migration narrative.

We have used the conceptual lens of desire to capture this becoming dimension of the intersection of life course dynamics and cross-border migration and to analyse the orientations towards the future this was driven by and generative of. Within migration studies, a focus on desire has been motivated to go beyond an understanding of aspiration as limited to pre-migration decision-making and for going beyond the idea of migrants as rational decision-makers (Carling and Collins 2018). For understanding aspirations, a focus on desire brings out the importance of the enacted, embodied, and felt dimensions of being and becoming in place and across space which in the context of migration is both driven by aspiration and also generative of it. Such analytics connect with the idea of 'emergent aspirations' coined by Zipin et al. (2015, p. 236) in the youth studies literature where aspirations are described as 'emerging among young people as their lives apprehend the presentbecoming-future' (emphasis as in original). Such aspirations are often not yet concretised verbally but transpire through emotions and work as affect.

As we have demonstrated in this article, acting on these conceptual ideas has implications for research and the presentation of research material. Conveying what can be learnt through and from such intimate and emplaced narratives is best done through detailed ethnographic accounts (Huijsmans 2018) and realising such accounts typically requires long-term, and slow forms of research. Furthermore, recognising and appreciating the temporalities (here generation discourses) and the various places, actors, and objects drawn into the assemblages comprising young migrants' narratives of migration necessitates an expanded understanding of young people's lifeworlds and the broader sets of relations and histories underpinning them. Significantly, this also illuminates the various silences and contradictions that constitute an equally important, yet muted, dimension in the construction and everyday reproduction of particular aspirational migrant subjectivities. 
Funding Funding was provided by the Economic and Social Research Council (Grant No. 1495944).

\section{References}

Aboim, S., and P. Vasconcelos. 2014. From Political to Social Generations: A Critical Reappraisal of Mannheim's Classical Approach. European Journal of Social Theory 17 (2): 165-183. https://doi. org/10.1177/1368431013509681.

Appadurai, A. 2004. The Capacity to Aspire: Culture and the Terms of Recognition. In Culture and Public Action, ed. V. Rao and M. Walton, 59-84. Stanford: Stanford University Press.

Baumgarten, B. 2013. Geração à rasca and Beyond: Mobilizations in Portugal After 12 March 2011. Current Sociology 61 (4): 457-473. https://doi.org/10.1177/0011392113479745.

Bourdieu, P. 1984. Distinction: A Social Critique of the Judgement of Taste. Cambridge, MA: Harvard University Press.

Cairns, D., K. Growiec, and N. de Almeida Alves. 2014. Another 'Missing Middle'? The Marginalised Majority of Tertiary-Educated Youth in Portugal During the Economic Crisis. Journal of Youth Studies 17 (8): 1046-1060. https://doi.org/10.1080/13676261.2013.878789.

Carling, J. 2002. Migration in the Age of Involuntary Immobility: Theoretical Reflections and Cape Verdean Experiences. Journal of Ethnic and Migration Studies 28 (1): 5-42. https://doi. org/10.1080/13691830120103912.

Carling, J., and F. Collins. 2018. Aspiration, Desire and Drivers of Migration. Journal of Ethnic and Migration Studies 44 (6): 909-926. https://doi.org/10.1080/1369183X.2017.1384134.

Cole, J. 2004. Fresh Contact in Tamatave, Madagascar: Sex, Money, and Intergenerational Transformation. American Ethnologist 31 (4): 573-588. https://doi.org/10.1525/ae.2004.31.4.573.

Collins, F.L. 2018. Desire as a Theory for Migration Studies: Temporality, Assemblage and Becoming in the Narratives of Migrants. Journal of Ethnic and Migration Studies 44 (6): 964-980. https://doi. org/10.1080/1369183X.2017.1384147.

De Haan, A., and B. Rogaly. 2002. Introduction: Migrant Workers and Their Role in Rural Change. Journal of Development Studies 38 (5): 1-14.

Edmunds, J., and B.S. Turner. 2005. Global Generations: Social Change in the Twentieth Century. The British Journal of Sociology 56 (4): 559-577.

Favell, A. 2008. Eurostars and Eurocities: Free Movement and Mobility in an Integrating Europe. Malden, MA: Blackwell.

Goulart, P., and A.S. Bedi. 2017. The Evolution of Child Labor in Portugal, 1850-2001. Social Science History 41 (2): 227-254. https://doi.org/10.1017/ssh.2017.3.

Gray, L.E. 2016. Registering Protest: Voice, Precarity, and Return in Crisis Portugal. History and Anthropology 27 (1): 60-73. https://doi.org/10.1080/02757206.2015.1113409.

Huijsmans, R. 2011. The EU's Ambiguous Position on Migrant Underage Workers. In Transnational Migration and Human Security: The Migration-Development-Security-Nexus, ed. T.-D. Truong and D.R. Gasper, 159-168. Berlin: Springer.

Huijsmans, R. 2018. 'Knowledge That Moves': Emotions and Affect in Policy and Research with Young Migrants. Children's Geographies 16 (6): 628-641. https://doi.org/10.1080/14733285.2018.14688 69.

Huijsmans, R. (ed.). 2016. Generationing Development: A Relational Approach to Children, Youth and Development. London: Palgrave Macmillan.

Knight, D.M., and C. Stewart. 2016. Ethnographies of Austerity: Temporality, Crisis and Affect in Southern Europe. History and Anthropology 27 (1): 1-18. https://doi.org/10.1080/02757206.2015.11144 80 .

Mapril, J., and R.L. Blanes. 2018. Austerity in Portugal: The 'Middle-Classification' of the Public Space, Migration and the Silences of History. In The Global Life of Austerity: Comparing Beyond Europe, ed. T. Rakopoulos, 103-114. New York: Berghahn Books.

Nóvoa, A. 2014. 'A Country on Wheels': A Mobile Ethnography of Portuguese Lorry Drivers. Environment and Planning A: Economy and Space 46 (12): 2834-2847. https://doi.org/10.1068/a140115p.

Pina-Cabral, J. 2018. The Millennial Conjuncture. Paper Presented at the Ten Years of Crisis: The Ethnography of Austerity, ISCTE-IUL, Lisbon, Portugal. 
Prazeres, L. 2019. Unpacking Distinction Within Mobility: Social Prestige and International Students. Population, Space and Place 25 (5): e2190. https://doi.org/10.1002/psp.2190.

Punch, S. 2020. Why Have Generational Orderings Been Marginalised in the Social Sciences Including Childhood Studies? Children's Geographies 18 (2): 128-140. https://doi.org/10.1080/14733 285.2019.1630716.

Sin, C., O. Tavares, and G. Neave. 2017. Student Mobility in Portugal: Grappling with Aversity. Journal of Studies in International Education 21 (2): 120-135. https://doi.org/10.1177/1028315316669814.

Stahl, G., D. Wallace, C. Burke, and S. Threadgold. 2019. Introduction: Using Bourdieu to Theorize Aspirations. In International Perspectives on Theorizing Aspirations: Applying Boudieu's Tools, ed. G. Stahl, D. Wallace, C. Burke, and S. Threadgold, 1-17. London: Bloomsbury Academic.

Theodossopoulos, D. 2018. Iphigenia's Dream: Threads of Generational Accountability in Times of Austerity. Paper Presented at the Ten Years of Crisis: The Ethnography of Austerity ISCTE-IUL, Lisbon, Portugal.

Zipin, L., S. Sellar, M. Brennan, and T. Gale. 2015. Educating for Futures in Marginalized Regions: A Sociological Framework for Rethinking and Researching Aspirations. Educational Philosophy and Theory 47 (3): 227-246. https://doi.org/10.1080/00131857.2013.839376.

Publisher's Note Springer Nature remains neutral with regard to jurisdictional claims in published maps and institutional affiliations. 